\title{
Strates
}

STRATES Matériaux pour la recherche en sciences sociales

$1 \mid 1986$

Mélanges

\section{Commerçants étrangers en France}

\section{Michèle Guillon}

\section{(2) OpenEdition}

\section{Journals}

\section{Édition électronique}

URL : http://journals.openedition.org/strates/347

DOI : $10.4000 /$ strates. 347

ISSN : $1777-5442$

\section{Éditeur}

Laboratoire Ladyss

\section{Édition imprimée}

Date de publication : 1 janvier 1986

ISSN : 0768-8067

\section{Référence électronique}

Michèle Guillon, «Commerçants étrangers en France », Strates [En ligne], 1 | 1986, mis en ligne le 08 décembre 2004, consulté le 08 septembre 2020. URL : http://journals.openedition.org/strates/347 : DOI : https://doi.org/10.4000/strates.347

Ce document a été généré automatiquement le 8 septembre 2020

Tous droits réservés 


\section{Commerçants étrangers en France}

Michèle Guillon 